Іванова Ірина Вікторівна кандидат педагогічних наук, доцент, доцент кафедри економіки, підприємництва і маркетингу, Черкаський державний бізнес коледж, 243, вул. В'ячеслава Чорновола, Черкаси, 18000, e-mail: irivik@gmail.com, https://orcid.org/0000-0002-4769-3620

\title{
СОЦІАЛЬНО-ПЕДАГОГІЧНІ ПЕРЕДУМОВИ СТАНОВЛЕННЯ ТА РОЗВИТКУ КУЛЬТУРОЛОГІЧНОГО ПІДХОДУ
}

Анотація. Культуротворча парадигма змісту навчання сучасного здобувача освіти вимагає пошуку нових стратегій, до яких належить культурологічний підхід. На думку автора, культурологічний підхід передбачає одночасне оволодіння фахом і формування навичок культурного усвідомлення, засвоєння культурологічних знань і формування культурологічної компетентності. У статті проаналізовано погляди вчених на поняття культурології. Проаналізовано історичні передумови культурологічного спрямування змісту освіти. У ході теоретичного аналізу філософської та педагогічної літератури розглянуто поняття: «культура» - як органічна частина цивілізації, система духовних цінностей, сума знань і досвіду, який дає змогу майбутнім фахівцям бути адекватними учасниками міжкультурної комунікації; «культурологічний підхід» - як стратегія навчання, що забезпечує формування у студентів професійної культурологічної компетентності через сприйняття культури носія мови.

Для виокремлення соціально-педагогічних передумов становлення та розвитку культурологічного підходу в історичній ретроспективі автор застосував методи теоретичного аналізу, синтезу, порівняння, узагальнення та систематизації наукової літератури з дидактики, філософії та культурології.

На основі проведеного аналізу констатовано, що мова, яка $є$ соціально обумовленою, перебуває у тісному взаємозв'язку з культурою народу. У зв'язку з цим посилюється увага на навчання іншомовного спілкування одночасно 3 навчанням культури. Доведено, що успішне виконання цього завдання можливе за умови використання культурологічного підходу до навчання професійного іншомовного спілкування.

Ключові слова: культура, культурологічний підхід, діалог культур, взаємозв'язок мови і культури, соціально-педагогічні передумови

Ivanova Iryna Viktorivna $\mathrm{PhD}$ in Pedagogical Sciences, Associate Professor, Department of Economics, Entrepreneurship and Marketing, Cherkasy State Business College, 243, Viacheslav Chrnovil St., Cherkasy, 18000, e-mail: irivik@gmail.com, https://orcid.org/0000-0002-4769-3620 


\section{SOCIO-PEDAGOGICAL PREREQUISITES FOR THE FORMATION AND DEVELOPMENT OF CULTUROLOGICAL APPROACH}

Abstract. The cultural paradigm of the content of educating modern students searches for new strategies. Culturological approach is one of them. According to the author, the culturological approach involves simultaneous development of professional and cultural awareness skills, the acquisition of culturological knowledge and the formation of culturological competence. The article analyzes the views of scientists on the concept of culturology. The historical preconditions of the culturological upgrading of the content of education are analyzed. In the course of theoretical analysis of philosophical and pedagogical literature, the concepts of culture and culturological approach are considered. Culture is referred to as an organic part of civilization, a system of spiritual values, and the amount of knowledge and experience that allows future professionals to be adequate participants in intercultural communication. Culturological approach is interpreted as a learning strategy that enables students to develop professional cultural competence through the perception of the culture of the representative of the community.

To highlight the socio-pedagogical preconditions for the formation and development of culturological approach in historical retrospect, the author uses the methods of theoretical analysis, synthesis, comparison, generalization and systematization of literature on didactics, philosophy and culturology.

Based on the analysis, it is stated that the language, which is socially conditioned, is closely related to the culture of people. As a result, there is a growing focus on teaching foreign languages simultaneously with teaching culture. It is proved that successful performance of this task is possible under the condition of using a culturological approach to teaching professional foreign language communication.

Keywords: culture, culturological approach, dialogue of cultures, interrelation of language and culture, social and pedagogical prerequisites.

Постановка проблеми. Відкриття кордонів, поширення глобалізаційних процесів довели, що у світі немає достатніх навичок комунікації між представниками різних культур, що не дозволяє цілеспрямовано підтримувати діалог між культурами. Виконання соціального замовлення держави на підготовку компетентних фахівців бізнес-сфери передбачає формування у них професійної іншомовної культурологічної компетентності. Культуротворча парадигма змісту навчання сучасного здобувача освіти вимагає пошуку нових стратегій, до яких належить культурологічний підхід. Культурологічний підхід передбачає одночасне оволодіння фахом і формування навичок культурного усвідомлення, засвоєння культурологічних знань і формування культурологічної компетентності.

Аналіз останніх досліджень і публікацій. Проблеми культурологічного оновлення змісту освіти, формування міжкультурної компетенції, продовжує посідати одне з пріоритетних місць у дослідженнях зарубіжних та вітчизняних 
науковців, а саме М.В. Бастун, С.П. Гвоздій, С.В. Машкіної, В.М. Пушкіної, Т.П. Усатенко, Л. О. Хомич тощо. У більшості публікацій визначають сутність культурологічного підходу у педагогіці в цілому і окремих іiі галузях зокрема, обгрунтовують його теоретичні засади і методологію. Однак, ще не було здійснено аналізу історичних передумов його виникнення.

Мета статті полягає у аналізі історичних передумов необхідності культурологічного оновлення змісту навчання іноземних мов.

Виклад основного матеріалу. Філософські дослідження культури, які бурхливо розвивались у науці, вказують на те, що людський індивід соціальнокультурно обумовлений. У середньовіччя, коли єдиними академічно визнаними мовами були латинська і грецька, вважали, що універсальні, загальні культурні знання засвоюються разом із оволодінням граматичними формами. Акценти робились на внутрішньому аспекті слова, особливо на граматиці, що, у свою чергу, негативно впливало на змістовий, національно-культурний аспект навчального процесу.

У період граматико-перекладного методу викладання головним напрямом роботи було засвоєння лексико-граматичної системи мови, тому ні текстів, ні діалогів, ні ілюстрацій, ні інших компонентів, здатних нести культурне навантаження, у підручниках не було. До недавнього часу єдиним науковим обгрунтуванням навчання іноземних мов вважався доступ до витворів світової літератури. Саме цей факт поклали в основу культурно-естетичної концепції методики навчання іноземних мов XIX століття. Однак граматико-перекладний i текстуально-перекладний методи мали очевидний недолік - вони ігнорували орієнтацію на справжню комунікацію. Протест проти цього недоліку започаткував Реформу навчання живих іноземних мов. Реформа супроводжувалася зростанням інтересу до культур, які обслуговуються іноземними мовами, що вивчаються. Відповідно до лінгвістичних концепцій про те, що кожна мова відображає світогляд народу, який iï створює, i що кожному народові притаманна своя система понять, прихильники нового на той час прямого методу навчання іноземних мов вважали, що зміст, виражений однією мовою, не можна адекватно передати іншою мовою. Представники прямого методу виступали за залучення відомостей про країну, мова якої вивчається, та про культуру в процес навчання мов. В. Фієтор, М. Берліц, Ф. Гуен пропонували включити в навчальний процес тексти 3 життя і культури народу; Ш. Швейцер і Е. Сімонет рекомендували використовувати схему базових знань: географічні відомості, історичні події, знайомство зі звичаями носіїв мови.

У 1925 році побачила світ „Методика та дидактика навчання нових іноземних мов" професора Марбурзького університету Е. Отто. Основною метою навчання іноземних мов автор вважав культурознавчу, яка полягала у вихованні молоді в німецькому національному дусі. Саме в такий спосіб, на його думку, найкраще досягається вивчення культури іншого народу, бо через знайомство 3 чужою культурою можна належно оцінити національну культуру [1, с. 13]. 
У цей період в Австрії виник напрям, а потім і школа під назвою "Wörter und Sachen“ („Слова та речі“), послідовники якого ставили за мету надати належну увагу соціальним чинникам у розвитку та існуванні мови. Вони наголошували, що зі зміною культури змінюють свій зміст і слова [2, с. 13].

Французькі науковці А. Мейе, Ж. Вандрієс, А. Доза робили спроби довести, що саме в мові відображається еволюція суспільства, його ідеологія та матеріальна культура, тому у навчанні мови як іноземної необхідно звертати увагу на культурно-історичні та соціальні аспекти [2, с. 14].

Розвиток соціологічних напрямів у лінгвістиці, зокрема, розвиток американської етнолінгвістики привів до твердження про те, що мова визначає свідомість людей, які нею спілкуються. Згідно з дослідженнями етнолінгвіста Уорфа, який зіставляв мову північноамериканських індіанців з європейськими мовами, різні народи, які спілкуються своєю мовою, мають відповідну систему понять, немов би своє мислення. Ця гіпотеза була використана деякими науковцями для побудови теорій навчання мов. Так, засновники аудіолінгвального методу Ч. Фриз і Р. Ладо стверджували, що потрібно не лише навчати мови, але й формувати нове іншомовне мислення. У зв'язку з цим вони пропонували поділити курс навчання іноземних мов на два етапи [2, с. 12]. На першому формуються окремі компоненти нового мислення поряд із навчанням мови, а на другому - завершується становлення в цілому іншомовної системи понять. Мова розглядалася ними як відображення історії, культури та побуту народу - носія цієї мови.

На початку XX сторіччя сформувалась наука культурологія. Про предмет і місце культурології у системі наукового знання не склалося єдиної думки. В Оксфордському словнику вказується на те, що слово Kulturologie уперше використав німецький учений В. Оствальд у 1913, а англійський термін culturology першим ужив у 1949 американський антрополог Л. Уайт. У тому ж словнику культурологія трактується як наука чи вчення про культуру [3]. У словнику Вебстера фіксується: „Culturology — наука про культуру; більш спеціальний зміст: деяка методологія, пов'язана 3 ім'ям американського антрополога Л. Уайта, що розглядав культуру як самодостатній процес, а культурні риси (інститути, ідеології та технології) — як незалежні від некультури чинники (від клімату, людського тіла, наших бажань і цілей)". Фундамент культурології був закладений у роботах зарубіжних учених XIX - XX століття (М. Вебер, В. Віндельбанд, Н. Гартман, Е. Гуссерль, Г. Зіммель, Е. Кассірер).

Становлення української культурологічної школи пов'язане з В. М. Перетцем, М. I. Марченком, І.П. Крип'якевичем, Д. В. Антоновичем, М. Семчишиним. Особливе місце в історії української культурології посідає концепція І. Огієнка, який прийняв мову як головну ознаку культурної ідентичності, через яку, на його думку, формується здатність до національного відтворення та до державного життя, оскільки із занепадом національної мови занепадає національна культура, гине нація, а $з$ нею і державницька ідеологія [4, с. 13-16].

Культурологія як наука перебуває у процесі становлення, пошуку своїх 
особливостей, об’єкта i предмета дослідження, вироблення адекватних дослідницьких методів і підходів щодо свого об'єкта. Є.А. Подольська, В.Д. Лихвар та К.А. Іванова визначають культурологію як систему знань про сутність, закономірності існування та розвитку, людське значення та способи пізнання культури [5, с. 6]. Тому, на їхню думку, важливим завданням теорії культури $€$ пізнання іiі сутності і виявлення законів та механізмів функціонування iii конкретних форм і аспектів. О.Л. Шевнюк вважає, що культурологія вивчає закони утворення, оформлення, закріплення і трансляції смислів життєдіяльності людства, і тому предметом культурології називає смисли буття людства, тобто ціннісно-смисловий аспект культури [6, с. 22]. На думку I.I. Тюрменко, культурологія вивчає культуру як цілісність, як особливу функцію і модель людського буття і $є$ емпіричною наукою, що аналізує конкретно-історичні явища культури та виявляє універсальні закономірності зародження, функціонування та зміни культурних феноменів [7, с. 7].

Мета дослідження культурології - це осягнення проблеми буття людини в усіх соціокультурних вимірах. Об'єктом культурології $є$ закономірності становлення і розвитку різних суб'єктів культури, сутність і зміст процесів збереження, трансляції, освоєння і зміни традицій, цінностей, норм. Основні завдання передбачають вивчення процесів взаємодії людини зі світом природи, соціуму, фізичного і духовного буття, відтак предметом дослідження $\epsilon$ штучне середовище, створене людиною; мова як універсальний засіб спілкування; знання норм і цінностей суспільства. О.Л. Шевнюк метою культурології вбачає розуміння культур, а тому серед завдань культурології виокремлює такі: опанування смислового простору культури; аналіз історичних і національних феноменів культури; дослідження морфології та типології культур; вивчення культурних кодів та комунікацій; оволодіння досвідом ефективних соціокультурних практик [6, с. 24] .

Культурологія вивчає не лише культуру в цілому, але й різноманітні сфери культурного життя. О.Л. Шевнюк серед найбільш усталених культурологічних категорій визнає такі: культурологічні об'єкти (культурні риси, артефакти, культурні системи і конфігурації), культурогенез, культурологічні властивості (функціональність, семантичність, комунікативність, універсальність, локальність), культурологічні смисли, ментальність, культурологічні тексти, знаки, символи, культурологічні норми (традиція, інновація, мода, стиль), міжкультурні взаємодії (запозичення, відтворення, синтез) [6, с. 25]. Одним із найбільш поширених понять в культурології $є$ поняття картини світу як вищої форми узагальнення, систематизації та інтеграції пізнавального досвіду людства [6, с. 27].

У 2003 році „Культурологію” введено як базову навчальну дисципліну в перелік обов'язкових предметів, що вивчаються у вищих навчальних закладах України. Культурологія, посідаючи важливе місце у блоку соціогуманітарних дисциплін, дає студентам знання про навколишній світ та механізми його функціонування через систему ціннісних орієнтацій, сприяє самоідентифікації 
особистості та визначенню нею свого місця в суспільстві. Предметом дослідження культурології як навчальної дисципліни є історичний та соціальний досвід людини, закріплений в традиціях, нормах, звичаях, законах тощо [7, с. 8].

Спираючись на висновки Леслі Уайта, визнаного засновника культурології як науки, багато дослідників характеризують цю галузь як науку про досягнення нації, етнічної групи у сфері матеріального і духовного розвитку, а також про особливі шляхи та прийоми досягнення ними означених факторів [8, с. 10]. Л. Уайт розвиває ідею „культурної детермінаціі” явищ у суспільстві та поведінці індивідів. Культура виступає для індивіда у формі значень, які передаються мовними знаками-символами [8].

Кожна людина належить до певної національної культури, яка містить в собі національні традиції, мову, історію, літературу. Економічні, культурні та наукові контакти країн і їх народів роблять актуальними теми, пов'язані 3 дослідженням міжкультурних комунікацій, співвідношенням мов i культур. Проблемам взаємозв’язку мови і культури присвятили свої праці В. Гумбольдт, С. Сепір, Р. Ладо та ін. Так, наприклад, В. Гумбольдт писав, що мова - це об'єднана духовна енергія народу, таємничим чином записана у вигляді звуків, і в такому вигляді, через взаємодію звуків зрозуміла всім, хто володіє цією мовою, і збуджує в них відносно однакову енергію, а різні мови - це різне сприйняття одного і того ж предмета. Учений приділяє багато уваги питанню про співвідношення мови i нації. Для встановлення кореляції між цими питаннями ним вводиться категорія „мовної свідомості народу”. Він розвиває думку про те, що багатоманітність мов - це не різниця позначення одного предмета, а різні бачення його. В концепції В. Гумбольдта мова розглядається не тільки традиційно - як засіб комунікації, але й як унікальний спосіб залучення до символічних кодів культури.

Суттєвий вклад у розуміння зв'язку мови і культури зробила відома лінгвістична гіпотеза Сепіра - Уорфа. Згідно 3 їхньою теорією, мислення, світогляд i поведінка людей лінгвістично детерміновані, тобто обумовлені характером і природою тієї мови, якою вони спілкуються. Реальний світ створюється завдяки мовним особливостям певної культури [9, с. 159]. На думку Є.Сепіра, мова - це путівник, який набуває все більшого значення як основа в науковому дослідженні культури. Він вважає, що система культурних моделей певної цивілізації фіксується в мові, яка виражає цю цивілізацію [9, с. 177]. Відповідно до досліджень Р. Ладо, кожна культура складається з функціональних одиниць, які мають свою форму, значення і дистрибуцію. Функціональні одиниці культури можуть не співпадати в різних культурах або за формою, або за значенням, або за дистрибуцією. Вся сукупність ідей, які стосуються взаємозв'язку мови і культури, мали велике значення для лінгвістики кінця ХХ століття. Ці чинники привели до виникнення нових напрямів дослідження і навіть нових наук.

На стику лінгвістики та культурології в кінці XX сторіччя виникла наука лінгвокультурологія, яка досліджує прояви культури народу, що відтворюються і закріплюються в мові. Термін ,лінгвокультурологія” виник у зв’язку з роботами 
фразеологічної школи, яку очолив В.Н. Телія. Лінгвокультурологія вивчає мову як феномен культури; це певне сприйняття світу крізь призму мови, коли мова виступає виразником особливої національної ментальності.

Поряд із лінгвокультурологією з'являється ще один напрям дослідження, який відображає взаємозв'язок мови i культури, - лінгвокраїнознавство. Порівнюючи поняття „лінгвокультурологія” i „лінгвокраїнознавство”, О.І. Зінов'єва зазначає, що об'єктом дослідження лінгвокраїнознавства є мовні одиниці різних рівнів, а лінгвокультурології - різні структури знань, обгрунтовані національним менталітетом і культурою.

Становлення і розвиток лінгвокраїнознавства мало важливе значення не лише для навчання російської мови іноземними студентами, але й було поштовхом для розвитку в цьому напрямі методики навчання іноземних мов шляхом перегляду цілей ії навчання та оновлення змісту за рахунок включення до нього культурного компоненту.

Лінгвокультурологія і лінгвокраїнознавство є суто лінгвістичними науками, оскільки вони вивчають аспекти мови, які відтворюють особливості національної культури, а методичний аспект залишається поза увагою. За таких умов володіння і процес оволодіння іншомовною комунікативною діяльністю почали кваліфікувати як міжкультурну комунікацію.

Поняття „міжкультурна комунікація” та „культурне усвідомлення” з'явились у зарубіжній педагогіці та дидактиці в 80-х роках XX сторіччя і вживались спочатку, в основному, в галузі теорії виховання. Л. Самовар та Р. Портер визначають термін „міжкультурне спілкування” як безпосереднє i опосередковане спілкування партнерів - представників різних культур, у процесі якого стикаються різні „перспективи” комунікантів, де складовими цих перспектив є ціннісні орієнтації, уявлення про універсалії та їх вербальні вираження, норми, моделі поведінки тощо; під час такого спілкування вдається або не вдається досягти взаєморозуміння. У дидактичній літературі представлені різні визначення міжкультурного або інтеркультурного (inter (англ.) - між) навчання. К. Крамш [10, с. 58] розуміє під інтеркультурним навчанням вимоги систематичного контрастування своєї та цільової культур, так званий „діалог культур"; Р. Піхт і Гізела Баумграц - міжнародний діалог; В. Ніке міжкультурний діалог; М. Байрам міжнародне громадянство; Г. Царате - процеси децентризму (в противагу етноцентризму); Г. Грош і В.Р. Леенен визначають інтеркультурне навчання як зміну переживань і поведінки, що відбувається у процесі взаємодії індивіда з іншокультурним середовищем; А. Томас визначає терміном „інтеркультурне навчання” процес, під час якого людина в результаті прямого або опосередкованого спілкування з іншокультурними ознаками змінює свій світогляд, мислення, відчуття і поведінку.

У зарубіжній теорії навчання з'явились поняття „міжкультурний” (intercultural) та „полікультурний” (multicultural), які характеризують дві педагогічні спроби зрозуміти i поєднати різні культури. Поняття „міжкультурний” використовується в Свропі для позначення процесу отримання 
інформації про звички, установи та історію суспільства, яке відрізняється від власного. На противагу цьому терміну у США широко використовується поняття „полікультурний”, яке поглиблює та урізноманітнює традиційний погляд на культуру через розходження в етнічній, соціальній і статевій належності в межах однієї нації [10, с. 4]. У 1974 році у США була створена організація SIETAR, що є найбільшою міжпредметною мережею для науковців і студентів, які досліджують проблеми міжкультурного спілкування.

Про усвідомлення культури країни, мова якої вивчається, спочатку говорили як про „п’яте вміння” поряд із читанням, письмом, аудіюванням і говорінням. Але, на думку К. Крамш, якщо мова - це соціальний феномен, то культура стає суттю навчання мови [10]. Відповідно до цього, усвідомлення культури - це насправді не „п'яте вміння”, а сума вмінь, про які доцільніше говорити як про компетенцію. Міжкультурна комунікативна компетенція широко досліджується у працях М. Бірама. Згідно 3 його теорією, міжкультурна компетенція - це здатність взаємодіяти іноземною мовою з людьми з інших країн і культур. Знання іншої культури пов'язане 3 мовною компетенцією через здатність адекватно користуватися мовою і розуміти іiі особливі значення і конотації.

Теорія „культурно-історичного розвитку особистості” Л.С. Виготського мала значний вплив на розвиток проблеми, що нами досліджується. Пізніше це питання вивчали Б.Г. Ананьєв, Л.І. Анциферова, Л.П. Буєва, Е.М. Верещагін, С.Л. Рубінштейн. Соціалізація людини, на їхню думку, відбувається під дією національної культури з урахуванням діалектики зовнішнього і внутрішнього, психічного і соціального, коли зовнішні соціальні умови опосередковуються внутрішніми індивідуальними чинниками. Неможливо зрозуміти генезис становлення особистості автономно від культурної спільноти. Але засвоєння національної культури має місце не лише під час соціалізації особистості.

Таким чином, очевидно, що успішний розвиток особистості, готової до діалогу культур, являє собою процес, який можна скеровувати, регулюючи результати засвоєння іншомовної культури. Цікавою з цього приводу є модель засвоєння чужої культури одного 3 провідних спеціалістів міжкультурної комунікації М. Беннета [9, с. 267-268]. Усвідомлення культурних відмінностей, за його моделлю, проходить декілька етапів: етноцентристський, до якого входять заперечення (ізоляція i сепарація), захист (дифамація, першість, зворотний розвиток), віддалення (фізичний універсалізм, трансцендентний універсалізм), i етнорелятивістський, у складі якого визнання (повага до відмінностей у поведінці, повага до відмінностей в системі цінностей), адаптація (емпатія, плюралізм), інтеграція (контекстуальна оцінка, конструктивна маргинальність).

Класифікація сучасних європейських підходів до формування культурного компоненту змісту навчання іноземної мови, запропонована дослідницею з Данії Карен Різагер, виглядає так [11, с. 20-21]:

1. Іншомовно-культурний підхід (foreign-cultural approach або target culture approach) бере свій початок приблизно з 1980. Він базується на 
концепції ознайомлення із культурою народу, мова якого вивчається. При цьому виключається порівняння чи проведення будь-яких паралелей iз культурними особливостями рідного чи іншого народів. Його метою $є$ досягнення тими, хто навчається, рівня комунікативної та культурної компетенції, що відповідає носієві мови. Таке явище отримало назву феномена вторинного етноцентризму (phenomenon of secondary ethnocentrism).

2. Міжкультурний підхід (intercultural approach) бере за основу положення, що різні культури структурно споріднені, або схожі. Тому можна говорити про взаємодію чи діалог культур. Невід'ємним елементом цього підходу є порівняння культурних особливостей народу, мова якого вивчається, та рідної культури.

3. Багатокультурний підхід (multicultural approach) визначається положенням про співіснування кількох різних культур у межах певної країни чи держави. Цей підхід бере до уваги етнічну та лінгвістичну різноманітність країн, мова яких вивчається. Міжкультурний i багатокультурний підходи мають чимало спільних рис, зокрема, положення про те, що різні культури існують у межах одного й того самого суспільства і є, по суті, гомогенними та взаємодіючими одна з одною.

4. Транскультурний підхід (transcultural approach) визначається на положеннях про взаємопроникнення елементів різних культур у результаті інтеграційних процесів, складовими яких $є$ міграції, туристичні поїздки, функціонування світових комунікаційних систем, глобалізація економіки тощо. Метою навчання в цьому випадку є готовність використовувати мову для міжнародного та міжетнічного спілкування в ситуаціях різного рівня лінгвістичної складності.

Останнім часом серед науковців досить часто звучить думка про необхідність нової концепції навчання, яка поєднувала б усі форми залежності мови від культурних чинників і могла б сприяти комплексному використанню в системі професійної підготовки фахівців різного профілю. До таких концепцій належать основні положення лінгвокультурознавства і соціокультурний підхід до навчання іноземних мов, запропонований В.В. Сафоновою. У 90-х роках А.П. Валіцькою була розроблена концепція культуротворчої школи, мета якої підготовка людини, здатної до культурного творіння, продуктивного діалогу 3 природою та соціумом. Р.Р. Агадуллін досліджує і обгрунтовує необхідність полікультурної освіти в Україні, основна мета якої, на його думку, полягає у формуванні особистості, вільної від негативних етнокультурних стереотипів, що володіє розвинутим почуттям розуміння інших культур і поваги до них, що вміє жити в мирі й злагоді з людьми будь-яких національностей і віросповідань, а отже, $\epsilon$ готовою до творчої життєдіяльності в полікультурному соціумі [12, с. 23-24].

3 розвитком і розповсюдженням в українській освіті комунікативного підходу до навчання іноземних мов значно більше уваги стали приділяти використанню мови в певних культурних і соціальних ситуаціях. Була зроблена 
спроба інтеграції лінгвістичного і соціокультурного аспектів у процесі навчання іноземної мови. У зв'язку з цим змінилося сприйняття основної мети та змісту навчання. У вітчизняній науковій літературі з'явився термін «соціокультурна компетенція!, яка передбачає знайомство 3 національно-культурними особливостями мовленнєвої поведінки і здатністю користуватись елементами соціокультурного контексту. О.О. Першуковою була досліджена універсальна концептуальна модель соціокультурної складової змісту навчання іноземної мови, яка в основі своїй має два аспекти - дидактичний, який складається зі знань, умінь і навичок, та виховний [11, с. 155-161].

Висновки. Для успішного формування професійної кудьтурологічної компетентності необхідне систематичне і широке включення елементів культури до навчального процесу з іноземної мови на всіх етапах іï вивчення. На нашу думку, досягти цього можна за умов використання культурологічного nidxоду до навчання іноземних мов. Предметна галузь, що підлягає вивченню і регулюванню в межах культурологічного підходу, включає умови та механізми оптимізації культур, процесів на загальнонаціональному та регіональному рівнях; на рівні соціально-культурної спільності. При цьому культурологічні матеріали мають сприяти ефективності мовних i мовленнєвих дій у повсякденному житті та розумінню феноменів повсякденності. У засвоєнні культурологічних знань вбачається необхідна умова адекватного вживання мови.

Культурологічне навчання іншомовного спілкування не має на меті лише передати конкретну інформацію. Насамперед ідеться про розвиток здатності сприймати іншого, усвідомлювати спільні риси й відмінності між різними культурами, а також про формування знань, умінь і навичок спілкуватися 3 іншими культурами та суспільствами.

Таким чином, 3 позицій культурологічного підходу процес навчання іноземної мови будується адекватно автентичним ситуаціям міжкультурного спілкування. Культурологічний підхід передбачає органічне поєднання лінгвістичних та екстралінгвістичних факторів у процесі навчання іноземної мови.

Узагальнивши результати теоретичного аналізу, ми робимо висновок, що питання культурологічного спрямування змісту навчання іноземної мови потребує особливої уваги. Зокрема, необхідно уточнити сутність дидактичної категорії ,зміст навчання професійного іншомовного спілкування” відповідно до культурологічного підходу до організації навчального процесу.

\section{Jimepamypa:}

1. Маслова В. А. Лингвокультурология. М. : Изд. центр «Академия», 2001. 208 с.

2. Миролюбов А.А. Культуроведческая направленность в обучении иностранным языкам. Иностранные языки в школе. 2001. №5. С. 11-15.

3. Compact Oxford English Dictionary. New Edition. Oxford: Clarendon Press, 1994.

4. Огієнко I. Наука про рідномовні обов’язки. Львів: Українська академія друкарства, вид-во «Фенікс», 1995. 44 с. 
5. Подольська Є.А. Лихвар В.Д., Іванова К.А. Культурологія. Київ: Центр навчальної літератури, 2003. $288 \mathrm{c}$.

6. Шевнюк О.Л. Культурологія. К.: Знання-Прес, 2004. 354 с.

7. Культурологія: теорія та історія культури. Зза ред. I.I. Тюрменко, О.Д. Горбула. Київ: Центр навчальної літератури, 2004. 368 с.

8. Тарасенко М.В. Нові можливості інтерпретації теми „Мій дім” (екологічний аспект) за культурологічним підходом. Іноземні мови. 2003. №4. С. 10-14

9. Почепцов Г.Г. Теория коммуникации. М.: Рефл-бук, К.: Ваклер, 2001. 656 с.

10. Kramsch, Claire. (1996). The Cultural Component of Language Teaching // Zeitschrift für Interkulturellen Fremdsprachenunterricht [Online], URL : http://www.spz.tu-darmstadt.de/projekt_ ejournal/jg_01_2/beitrag/kramsch2.htm

11. Першукова О. Сучасні підходи до формування соціокультурного компонента змісту навчання іноземних мов в країнах Свропи/ Шлях освіти. 2003. №3. С. 19-22.

12. Агадуллін Р.Р. Полікультурна освіта: методолого-теоретичний аспект. Педагогіка i психологія. 2004. №3. С. 18-29.

\section{References:}

1. Maslova, V.A. (2001) Lingvokulturologiya [Lingua culturology] M. Izd. Tsentr Akademiya. 208 [in Russian].

2. Miroliubov, A.A. (2001) Kulturovedcheskaya napravlennost v obuchenii inostrannym yazykam [Cultural vector of teaching foreign languages]. Inostrannye yazyki v shkole. No. 5. 11-15 [in Russian].

3. Compact Oxford English Dictionary. New Edition. Oxford: Clarendon Press, 1994 [in English].

4. Ohiyenko, I. (1995) Nauka pro ridnomovni obovyazky [Science about native language duties]. Lviv: Ukrainska akademiia drukarshva, vyd-vo Feniks. 44 [in Ukrainian].

5. Podolska, Ye. A., Lykhvar, V.D., Ivanova, K.A. (2003) Kulturologiia [Culturology]. Kyiv. Tsentr navchalnoi literatuty. 288 [in Ukrainian].

6. Shevniuk, O.L. (2004) Kulturologiia [Culturology]. K. Znannia-Pres. 354 [in Ukrainian].

7. Kulturologiia:teoriia ta istoriia kultury (2004) [Culturology: theory and history of culture]. Za red. I.I. Tiurmenko, O.D. Horbula. Kyiv Tsentr navchalnoi literatuty 368 [in Ukrainian].

8. Tarasenko, M.V. (2003) Novi mozhlyvosti interpretatsii temy. [New opportunities to interpret a topic] Feorign languages. No4. 10-14 [in Ukrainian].

9. Pocheptsov, G.G. (2001) Teoriia Kommunijatsii [Theory of communication] M.: Refl-buk, $K$ Vakler. 656 [in Russian].

10. Kramsch, Claire. (1996). The Cultural Component of Language Teaching // Zeitschrift für Interkulturellen Fremdsprachenunterricht [Online], URL : http://www.spz.tu-darmstadt.de/projekt_ ejournal/jg_01_2/beitrag/kramsch2.htm [in English]

11. Pershukova, O. (2003)Suchasni pidkhody do formuvannia sotsiokulturnoho komponenta [Modern approaches to forming socio-cultural component]. Shliakh osvity. No3. 19-22 [in Ukrainian].

12. Ahadullin, R.R. (2004) Polikulturna osvita [Polycultural education]. Pedahohika I psykhologiya. No 3. 18-29 [in Ukrainian]. 